Vol. 6(4), pp. 66-71, J une 2014

DOI: $10.5897 /$ J MA2014.0300

Artic le Number. 1CC 185045710

ISSN 2141-2308

Copyright (C) 2014

Author(s) retain the copyright of this article

http://www.academic joumals.org/J MA
Journal of Microbiology and Antimicrobials

\title{
Yeasts in the mammary environment of the cattle in the region of Sidi M'hammed Ben Ali, Wilaya of Relizane, Algeria
}

\author{
Akdouche L.*, Aissi M., Zenia S. and Saadi A. \\ Ecole Nationale Supérieure Vétérinaire-Alger, BP.161, cinq Maisons, Alger, Algerie.
}

Received 7 January, 2014; Accepted 20 May, 2014

\begin{abstract}
Mastitis is one of the principal pathologies in the dairy bovine exploitation. Most of the cases are caused by bacteria, but some are caused by fungi. The objective of our study was to evaluate the occurrence of these fungi in mammary glands of 39 cows (mastitic and clinically healthy cows) belonging to two farms (four exploitations using manual milking and three exploitations using milking machine) in the area of Sidi M'hammed Ben Ali, Wilaya of Relizane and to assess some risk factors (the tubes of drug, animal excretion, goblets-milkers, the milkers' hands and the litter). For this purpose, 150 samples of milk and 94 swabs were used. Our results reveal the presence of a heavy load of fungi cells in healthy and mastistic milks, with a strong frequency of Trichosporon sp. $(43,58 \%)$ followed by Candida $\mathrm{sp}$. $(30.76 \%)$. The same yeasts were isolated from swabs.
\end{abstract}

Key words: Mastitis, fungi, antibiotics, milking machine, the milker, Algeria.

\section{INTRODUCTION}

Mycotic mastitis was described from the beginning of the last century (Klein, 1901). This mastitis aroused some skepticism and numerous debates because the incriminated agents are often contaminants of the outside or the common saprophytes. Although still inadequately known, they seem to draw the attention of pathologists, especially since the acceptance of everyday treatment (intra-mammary antibiotic). The rates of the observed mycotic mastitis vary from 0.34 (Loftsgard et al., 1960) to 3.9\%. Swinne-Desgain (1971) and Fortier (1990) said yeasts are responsible for $1.76 \%$ cases of mastitis (clinic and sub-clinic). Milk from a healthy udder does not contain either mushrooms or bacteria. It is better to speak about a fungal basic flora, resulting from the environment (dust resulting from feeds, equipment of collection as well as those of animals and even man). It is very common to find in the unpasteurized milk yeasts of the genre, Candida and mold, Penicillium, which can alter some dairy products.

Mycotic mastitis is split into two big groups according to the moment of appearance: primary mycotic Mastitis (bacterial preliminary mastitis) and secondary mycotic mastitis. The latter appears often straightaway, without antibiotic treatment or generally follows a bacterial

*Corresponding author. E-mail: leilakdouche@yahoo.fr. Tel: 0662.54.92.49.

Author(s) agree that this article remain permanently open access under the terms of the Creative Commons Attribution License 4.0 International License 
Table 1. Sampling plan.

\begin{tabular}{lccc}
\hline \multirow{2}{*}{ Nature of the sampling } & \multicolumn{3}{c}{ Number of samples } \\
\cline { 2 - 4 } & Manual milking & Milking machine & Total \\
\hline Number of cows & 17 & 22 & 39 \\
Numbers of milk samples & 65 & 85 & 150 \\
Numbers of anal swabs & 17 & 22 & 39 \\
Numbers of vaginal swabs & 13 & 22 & 35 \\
Number of swabs & 0 & 2 & 2 \\
Number of swabs on the hands of the milker & 3 & 0 & 3 \\
Number of swabs on creams Antibiotics & 12 & 0 & 12 \\
Numbers of litter samples & 0 & 3 & 3 \\
\hline
\end{tabular}

mastitis or an intramammary administration of antibiotics by diathélique way. According to some authors (Bertslinger et al., 1964), the first ones would represent $30 \%$ cases and the second $70 \%$ cases.

In Algeria, very few studies have been done on the prevalence of the fungal mastitis in the dairy bovine farms as well as on various factors favoring their appearance and development (Mebarki, 2007; Ksouri, 2008). So, the objective of the study is to determine the prevalence of mastitis caused by yeasts and to know the number of risk factors in some dairy bovine farms in Relizane.

\section{MATERIALS AND METHODS}

\section{Distribution of a questionnaire}

Pre-investigation was done in the last quarter of the year 2007 and the first half of 2008 to estimate the epidemiological situation of this pathological entity within the dairy beef herd in the region of Relizane. For that purpose, a questionnaire was distributed to the veterinarian practitioners. This investigation is on the breeding technique, frequency of the clinical mastitis in this breeding and the percentage use of antibiotics in the treatment of clinical mastitis.

\section{Choice of farms}

Four dairy farms with manual milking and tree with machine milking were used in this study. This selection was based on the comparison of both types of milking. All the farms exist in the same region- Sidi M'hammed Ben Ali, Wilaya de Relizène.

\section{Nature and number of samples}

A total of 244 samples were collected by the veterinarian practitioners of Sidi $\mathrm{M}^{\prime}$ hammed Ben Ali's region. That is 150 samples of milk taken from 39 existing cows in 7 farms. The simples were obtained with different mammary glands health status:19 cows with healthy mammary glands, 15 cows with subclinical mastitis as determined by the California Mastitis Test (CMT) and 05 cows with clinical mastitis, defined as follows: swelling, reduced milk flow and abnormal milk appearance, fever, inappetence, ataxia. CMT was used to identify subclinical mastitis on mammary gland of the cows. For this study, milk simples from gland affected with subclinical mastitis were included when the reaction to CMT was at least grade 1 . This corresponds with an appearance of viscous milk that does not adhere to the bottom of CMT plate, and correlates with $400,000-1,500,000$ somatic cells $/ \mathrm{ml}$ (Scott et al., 1986) (6 milk sampling emptied of their tube because they were badly kept), 91 swabs [39 anal swabs and 35 vaginal swabs of which four were badly kept), two swabs on milking machine, 3 on the hands of the milkers and 12 swabs of antibiotic creams. And at the end, three samples of litter were got back.

From every cow during lactation, four takings of milk (a taking of milk of every trayon), an anal swab, and a vaginal swab were taken once during all the period.

In every breeding with manual milking, swabbing was done by the hands of the milker before the milking (factor of contamination), there was recovery of the tubes of antibiotic cream (factor of release) used for the treatment of cows clinically and a sample of the litter was collected just before its renewal (factor of enrichment). Some takings were made in the breeding with machine milking except swabbing of the milkers' tumblers of the milking machine (factor of contamination) (Table 1).

\section{Milk sampling}

The correct realization of the sampling procedure was a necessity, in terms of the ubiquity of fungi which can contaminate the milk. The characteristics of the surrounding atmosphere were noted. The cows' environment was not loaded with dust (hays moving nearby and agitated animals). If such was the case, the animals of the dusty premises must have gone out. The milk sampling was realized according to the protocol of Guerin and Guerrin-Faublee (2007), which consists of washing the milkers' hands with a disinfecting soap, identifying the flask (in wide opening) with indelible felt-tip: number of the cow, the mammary gland quarter (FR, FL, RR or RL), date and time. The udder was carefully washed and wiped; the rough drafts of milk for rinsing the canal of the udder were eliminated (not more than 2 jets, otherwise there would be risk of the taking having germs). The teat canal of the udder was disinfected with a compress soaked with alcohol at $70^{\circ} \mathrm{C}$; the sterile flask was opened to maintain the openings managed downward. The rubber was kept in the same hand without touching the inside; some milliliters of milk were taken and recorded in the flask. Every udder was disinfected before taking the milk of the corresponding district. Finally, the takings of milk were kept in $-20^{\circ} \mathrm{C}$ until the day of their analysis.

\section{Mycological analyses of the milk}

Mycological analysis was realized in the laboratory of Parasitology Mycology of the Veterinary Graduate School- Algiers. It consists of a direct examination of the samples of milk, after vital staining. Milk 
samples were centrifuged and the sediment was inoculated on the surface of Sabouraud Dextrose Agar (SDA) (QUELAB, Laboratories INC and code: QB-39-3806) added of chloramphénicol (QUELAB, Laboratories INC and code: QB-39-3806) and incubated for 3 days at $25{ }^{\circ} \mathrm{C}$. Finally, isolated yeasts and filamentous fungi were identified using microscopic characterization. Yeasts isolated were identified by the gallery Pasteur (gallery Auxanogramme) (DIMED, code: 15300Algeria). This identification was performed taking into consideration morphological characteristics, like formation of chlamydoconidium, pseudohyphae and germinal tube development. This gallery is composite due to its various cultural middle and various tests for the precise identification of yeasts.

1. Middle Sabouraud/Chloramphénicol at $37^{\circ} \mathrm{C}$ : this test allows one to highlight the potential pathogenic character of the yeast when it develops in a temperature, bordering the corporal temperature.

2. Middle Sabouraud/Actidione; this test allows one to highlight colonies sensitive to Actidione

(Cycloheximide). Colonies having grown on this middle are considered resistant to Actidione (R); colonies not having grown on this middle are considered sensitive to Actidione (S).

3. Middle with cream of rice (rice cream): this middle favors the production of chlamydospores characteristics of Candida albicans in anaerobic middle.

4. Middle with serum for blastèse: the serum of bovine is used as middle to favor the production of Candida's typical germinal albicans tubes (test of germination).

5. Middle in the urea Indole: this test allows one to look for the hydrolysis of the urea. The change of the middle colour of yelloworange to purple-red corresponds to the secretion of an uréase. The yeast which turns the middle to red in $4 \mathrm{~h}$ is $\mathrm{C}$. neoformans.

A quantitative search for mushrooms (counting of colonies) and qualitative search (the various tests for identification) are made. For the identification of the genre and species of yeasts, the key of identification of yeasts proposed by Drouhet and Dupont (1985) was used.

\section{The anal, vaginal swabs and the material of milking}

The vaginal and the anal excretions were collected by swabbing in the perineum and vaginal regions. Swabbing of goblets was donemilkers of milking machines only in two dairy cow farms and swabbing of the hands of the milking men before the milking.

Swabbings were made by direct scattering of the swab on the surface of the SDA plates added to chloramphenicol. After incubation for 3 days at $25^{\circ} \mathrm{C}$, the colonies of yeasts were identified as previously.

\section{The litter samples}

The collected litter was deposited in one sterilized conical glass cup containing sterile physiological water, then the whole was homogenized and the rest was left for $30 \mathrm{~min}$. Some gouts of the sediment are then inoculated on SDA added to chloramphénicol. Cultures were incubated for 3 days at $25^{\circ} \mathrm{C}$.

\section{RESULTS}

\section{Results of the questionnaire distributed to the veterinarian practitioners}

The veterinarians in charge of the follow-up of the bovine breeding note that the measures of hygiene are absent.
Indeed, $60 \%$ of the milkers do not disinfect their hands before and after every milking. The udder is not disinfected before the milking in $45.71 \%$ cases. The majority of the breeding are done in hindered stall $(54.85 \%) ; 57.14 \%$ of the breeders use the same rag for the disinfection of the udder and in $65.71 \%$ cases, this rag is not disinfected after each use; $25.71 \%$ of the farmers disinfect their milking material once a week; $17.14 \%$ of the breeders change the cow litters only once a week.

This report thus incited us to start a study on prevalence of the mastitis of fungal origin.

\section{Results of the mycological analysis of the samples collected}

Of the 244 samples realized, 91 are positive, that is, $37.3 \%$ and 78 fungal species were identified: 35 species in the breeding with manual milking namely Candida $s p$ (25.7\%), Trichosporon sp. (48.6\%), Rhodotorula sp. (8.6\%), Cryptococcus sp. (2.9\%), Torulopsis sp. (2,9\%), Penicillium sp. (8.6\%), Aspergillus sp. (2.9\%) (Table 4); 43 species in the breeding with machine milking namely Candida sp. (34.9\%), Trichosporon sp. (39,5\%), Rhodotorula sp. (9.3\%), Cryptococcus sp. (4.6\%), Torulopsis sp. (2.3\%), Penicillium sp. (7\%) and Aspergillus sp. (2 .3\%) (Table 2).

\section{DISCUSSION}

Fungal cultures were observed in 68 samples of milk (Table 3). A study was done on the mammary infection of dairy cows in Sidi M' Hammed Be Ali's region, Wilaya of Relizane, from December 2007 to May 2008.

In our survey, the mycological examination of the milk samples and the realized swabs showed the presence of yeasts and filamentous fungi, with a higher frequency of yeasts (Table 3 ). This is in line with that of the literature. Indeed, the most frequent yeasts genus were Candida (30. 76\%) and Trichosporon (43. 58\%) (Table 4). Many authors noted that the fungal bovine mastitis is predominantly caused by yeasts (Swinne-Desgain, 1971; Kuo and Chang, 1993; Aalbaek et al., 1994; Watts, 1988; Lagneau et al., 1996; dos Santos and Marin, 2004).

The mycological analysis also revealed that, the same genre of yeasts was found in both types of exploitations namely Candida, Trichosporon, Rhodotorula, Cryptocoques and Torolupsis (Costa et al., 1993; Krukowski et al., 2001; Krukowski et al., 2006); with a higher frequency for Candida and Trichosporon genres (30.76; 43.58\%) and then Rhodotorula (7.69\%) and Cryptocoques (3.84\%) (Table 4). All these fungal agents, with the exception of Rhodotorula have been detected before as pathogenic agents in numerous inquiries on fungal mastitis (Moulinier, 2003). Prevalence of the 
Table 2. Various species of yeasts and molds isolated.

\begin{tabular}{|c|c|c|c|}
\hline Genre & $\%$ & Species & Number \\
\hline \multicolumn{4}{|c|}{ Breeding with manual milking } \\
\hline & \multirow[t]{5}{*}{25.7} & Candida zeylanoides & 1 \\
\hline & & Candida pseudotropicalis & 5 \\
\hline \multirow[t]{3}{*}{ Candida sp. } & & Candida guilliermondii & 1 \\
\hline & & Candida tropicalis & 1 \\
\hline & & Candida parapsilosis & 1 \\
\hline \multirow{2}{*}{ Trichosporon sp. } & \multirow[t]{2}{*}{48.6} & Trichosporon cutanium & 10 \\
\hline & & Trichosporon capitatum & 7 \\
\hline Rhodotorula sp. & 8.6 & Rhodotorula rubra & 3 \\
\hline Cryptococcus sp. & 2.9 & Cryptococcus terreus & 1 \\
\hline Torulopsis sp. & 2.9 & Torulopsis pulcherrima & 1 \\
\hline Penicillium sp. & 8.6 & Penicillium $s p$ & 3 \\
\hline Aspergillus sp. & 2.9 & Aspergillus sp & 1 \\
\hline Total & 100 & & 35 \\
\hline \multicolumn{4}{|c|}{ Breeding with machine milking } \\
\hline & \multirow[t]{2}{*}{34.9} & Candida zeylanoides & 1 \\
\hline & & Candida pseudotropicalis & 2 \\
\hline \multirow[t]{3}{*}{ Candida sp. } & & Candida guilliermondii & 7 \\
\hline & & Candida tropicalis & 4 \\
\hline & & Candida lusitaniae & 1 \\
\hline \multirow{3}{*}{ Trichosporon sp. } & \multirow[t]{3}{*}{39.5} & Trichosporon cutanium & 8 \\
\hline & & Trichosporon capitatum & 6 \\
\hline & & Trichosporon fermentens & 3 \\
\hline Rhodotorula sp. & 9.3 & Rhodotorula glutinis & 4 \\
\hline Cryptococcus sp. & 4.6 & Cryptococcus terreus & 2 \\
\hline Torulopsis sp. & 2.3 & Torulopsis glabrata & 1 \\
\hline Penicillium sp. & 7 & Penicillium $s p$ & 3 \\
\hline Aspergillus sp. & 2.3 & Aspergillus sp & 1 \\
\hline Total & 100 & & 43 \\
\hline Total & & & 78 \\
\hline
\end{tabular}

Table 3. Frequency positive samples according to the milking procedure.

\begin{tabular}{lccc}
\hline Milking procedure & Number of milk samples & Positive samples & Frequency (\%) \\
\hline Manual milking & 65 & 30 & 46.15 \\
Machine milking & 85 & 38 & 44.70 \\
Total & 150 & 68 & 45.3 \\
\hline
\end{tabular}

fungal mastitis varies from 1 to $44 \%$ according to authors' number (Loftsgard et al., 1960; Monga et al., 1971; Swinne-Desgain, 1971; Farnsworth et al., 1972; Kumer et al., 1975; Fenizzia et al., 1976; Awad et al., 1980; Ramisse et al., 1982).

Global frequency observed on the present study was considered at $45.33 \%$ for the exploitations with clinical mastitis and subclinical mastitis (Table 3), which is similar to those of Swinne and Desgain (1971). This frequency may be explained by the animal management put in place in the visited dairy farms in the region of Sidi $\mathrm{M}^{\prime}$ hammed Ben Ali (results of the questionnaire).
The genus Trichosporon was quoted by several authors as being a potential pathogenic fungus; in particular, T. capitatum, and T. cutaneum (Loftsgard et al., 1960; Fameree et al., 1970). The present study highlighted these species with a $43.58 \%$ rate $(23,06 \%$ for $T$. cutaneum, $16.66 \%$ for $T$. capitatum), higher than the rates found in a survey done by Mebarki (2005) in Algiers $(19.25 \%)$ on dairy exploitations of subclinical mastitis. Other authors pointed to lower rates, such as Moretti et al. (1998), who isolated T. capitatum in $31.2 \%$ cases and T. cutaneum in $18.72 \%$ cases in Italy. Aalbaek et al. (1994) described five cases of mastitis caused by $\mathrm{Tr}$ 
Table 4. Frequency of fungi isolations in the samples.

\begin{tabular}{lc}
\hline Genre & Percentage (\%) \\
\hline Candida spp. & 30.76 \\
Trichosporon spp. & 43.58 \\
Rhodotorula spp. & 8.97 \\
Cryptococcus spp. & 3.84 \\
Torulopsis spp. & 2.56 \\
Penicillium spp. & 7.69 \\
Aspergillus spp. & 2.56 \\
\hline
\end{tabular}

Table 5. Summary of the number of yeasts and filamentous fungi isolated from milk.

\begin{tabular}{lcc}
\hline Fungi & Manual milking & Machine milking \\
\hline Yeasts & 40 & 46 \\
Moulds & 08 & 06 \\
Total & 48 & 52 \\
\hline
\end{tabular}

capitatum in Denmark, which is lower than that of this present result (13 cases). Costa et al. (1993) have described 21 mastitis cases caused by $T$. cutaneum in Brazil.

Concerning the genus, Candida, its strong predominance $(30.76 \%)$ in the whole of the positive samples confirms the importance of this yeast, often evoked as the main genus in the etiology of mycotic mastitis (Fameree et al., 1970; Farnsworth et al., 1972; Richard et al., 1980; Yeh et al., 1988; Kuo and Chang, 1993; Aalbaek et al., 1994; Lagneau et al., 1996; dos Santos et al., 2004). This frequency of Candida isolation was lower than that recorded in the region of Algiers by Mebarki (2005) (52.07\%) and in the South of Brazil by Spanamberg et al. (2008) (37.9\%), but superior to that (17.3\%) noted by Sailor et al. (2004) in Brazil.

Prevalence of the fungal mastitis according to the milking modality was almost the same: in the manual milking, it is $46.15 \%$ and in the machine milking, it is $44.70 \%$. This means that there is independence between the positive milk samples and the milking procedure at the beginning. The difference is not significant $(p>5)$. The Chi-square test of independence was used for the comparison of both methods (manual milking and machine milking). This indicates that the problem does not settle at the level of the method of milking but in the conditions of the milking progress (the factors of enrichments, factors of releases and factors of contamination) (Table 5).

\section{Conclusion}

The frequency of fungal mastitis is underestimated in Algeria. The present study shows cases of fungal mastitis found in two types of exploitations (manual milking or machine milking). The isolation of the same genus of fungi in an almost similar percentage in both milking systems confirms the idea. This leads one to conclude that the problem of the fungal mastitis is not only connected to the milking modality but is connected to the conduct of farmers and the hygienic practices applied during the milking. The hygiene practices in the stables of the dairy farm do not have to be an additional act in the conduct of the farmers but a regular component of the farm management. With the aim of limiting the increase of the fungal mastitis, it is important to establish a specific diagnosis on healthy and pathological milk to modulate a treatment according to the etiology and clinical aspect of mastitis.

\section{Conflict of Interests}

The author(s) have not declared any conflict of interests.

\section{REFERENCES}

Aalbaek B, Stenderup J , Jensen HE, Valbak J, Nylin B, Huda A (1994). Mycotic and algal bovine mastitis in Denmark. APMIS, 102:451-456.

Awad FI, El moula A, Fayed A (1980). Studies on mycotic mastitis in Egypt. J. Egypt. Vet. Med. Assoc .40(3):35-41.

Bertslinger HU, Schweizer R, Scholer HJ (1964). Hefen als mastitis erreger beim rind.Schweiz; Arch.Tierheilk. pp.106, 158,166.

Costa EO, Gandra CR, Pires MF, Teixeira CM (1993). Survey of bovine mycotic mastitis in dairy herds in the State of S.o Paulo, Brazil. Mycopathologia. 124(1):13-17.

Dos santos RC, Marin JM (2004). Isolation of Candida spp.from mastitic bovine milk in Brazil. Mycopathologia, 59:251-253.

Drouhet E, Dupont B (1985), Les champignons levuriformes d'intérêt médical. Laborama, Revu d'information. Avril, Nº 21 :3-12.

Fameree L, Swinne-desgain D, Cotteleer C (1970). Mammites, antibiotiques, levures. Ann. Med. Vet. 114:389-409.

Farnsworth RJ, Sorensen DK (1972). Prevalence and species distribution of yeast in mammary glands of dairy cows in Minnesota. Can. J. Comp. Med. 36(4):329-332.

Fenizzia D, De anseris P, Cicala G (1976). Mastitis bovina subclinica attri buibile ad Aspergillus fumigatus. Atti Soc.Ital.Sci .Vet. $n^{\circ} 29$ :664668.

Fortier G (1990). Mammites Mycosiques des bovins, flore fongique du lait, pathogénie et moyen de lutte. Thèse AlFort. Paris, France, p. 130.

Guerin P, Guerin-faublee V (2007). Les mammites de la vache laitière. Thèse docteur vétérinaire. Ecole nationale vétérinaire de Lion. pp. 54-58.

Klein E (1901). J. Hyg. 11,665. Quoted by: Loftsgard G, Lindquist K (1960). Bovine mycotic mastitis. Acta. Vet.Scand.

Krukowski H, Tietze M, Majewski T, R.ZAŠSKI P (2001), Survey of yeast mastitis in dairy herds of small-type farms in the Lublin region, Poland. Mycopathologia, 150(1):5-7.

Krukowskl H, Lisowski A, Rozanski P, Skorka A ( 2006), Yeasts and algae isolated from cows with mastitis in the south-eastern part of Poland. Pol. J. Vet. Sci. 9(3):181-184.

Ksouri S (2008).Contribution à l'etude des mammites fongiques des bovins dans deux élevages laitiers de la region de guelma.Thèse de Magistère. ISV EL Taref. p.154.

Kumer S, Dhillon SS (1975). Mastitis caused by fungi. Indian Vet. J: 52:125-128.

Kuo CC, Chang CH (1993). Isolation of fungi from the mastitic milk of dairy cattle. J. Chin. Soc. Vet. Sci. 19:221-227.

Lagneau PE, Lebtahi K, Swinne D (1996). Isolation of yeasts from bovine milk in Belgium. Mycopathologia 135:99-102. 
Loftsgard G, Lindquist K (1960), Bovine mycotic mastitis. Acta. Vet. Scand. 1:201-220.

Mebarki M (2007). Contribution à l'étude des mammites mycosiques dans quelques élevages bovines laitiers de la région d'Alger. Thèse de Magistère. ENSV, Alger.183p.

Monga DP, Kalra DS (1971). Prevalence of mycotic mastitis among animals in Haryana. Ind. J. Sci. 41:813-816.

Moretti A, Pasquali P, Mencaroni G, Boncio L, Piergili FD (1998). Relationship between cell counts in bovine milk and the presence of mastitis pathogens (yeasts and bacteria). Zentralbl Veterinarmed B., 45(3):129-132.

Moulinier C (2003). Parasitologie et mycologie médicale, éléments de morphologie et de biologie. E.M. Inter-édition Médicales internationales. France: pp. 698, 699, 703, 704,780.

Ramisse J, Brement AM, Lamarre C, Viaud MA, Breard A (1982). Résultats d'une enquête sur les mammites Vendée. Point Vétérinaire. 13:63:63-73.

Richard JL, Mac Donald JS, Fichtner RE, Anderson AJ (1980). Identification of yeasts from infected bovine mammary gland and their experimental infectivity in cattle. Am. J. Vet. Res. 41(12):1991-1994.

Scott EM, Gorman SP, McGrat SJ (1986). An assessment of the fingicidal activity of antimicrobial agents for hard-surface and skin disinfection. J. Clin. Hosp. Pharm. 11:199-205.
Spanamberg A, Wüender A, Brayer PDI, Argenta J, Cavallini SEM, Valente $P$, Ferreiro $L$ (2008). Diversity of yeasts from bovine mastitis in Southern Brazil. Rev. Iberoam. Micol. 25:154-156.

Swinne-Desgain D (1971). Isolement de levures à partir de laits de vaches. Cahiers de Med. Vet. 40:57-63.

Watts JL (1988). Etiological agents of bovine mastitis. Vet. Microbiol. 16:41-66.

Yeh SG, Chung KY, Cho HT (1988). Prevalence of yeasts in bovine mammary gland infections and teat cups of milking machines. Korean J. Vet. Res. 28:361. 